MP-373 前立腺肥大症における中葉肥大の検討

\section{原三信病院 泌尿器科”}

山口秋人"分田 裕順"向井尚一郎”武井実根雄"

【目的】前立腺肥大㹥例において、中葉肥大の有無に上って、ど のような排尿障害の違いがあるか検討した。【方法】1986年から 1999年までにTUR-Pを施行した2439例のうち、pressure flow studyのデータがそろった798例を対象に、中葉肥大を認める278 症例（34.8\%）の検討を行った。【結果】排水笳収縮力は中葉肥 人を認める症例で71.9\%、認めない症例で $53.3 \%$ が正常であった。 排尿笳收縮力正常例で閉塞の程度をShaefer のnomogram 上で評 価すると、中葉肥大を認める症例では $89.0 \%$ が、認めない症例で は79.4\%が、閉塞が4以上の高度であった。また中葉肥大を認め

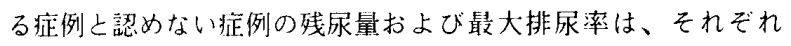
$128.0 \mathrm{ml}$ と $109.7 \mathrm{ml}$ および $7.6 \mathrm{ml} /$ 秒と $8.7 \mathrm{ml} /$ 秒で、中 葉肥大を認める群が有意心、上り残疗量が多く最大排尿率が小さ かった。【結論】以上より中葉肥大を認める症例はhigh pressure low flowの症例が多く、TUR-Pにより改善を期待できる症例が多 いと考えられた。

前立腺肥大症 中葉肥大 PFS

\section{MP-374 経尿道的前立腺切除重量/超音波推定重 比と術後早期他覚所見改善度との関連につ いて一前立腺肥大症症例での検討一}

\author{
福島県立医科大学 医学部 泌尿器科”
}

横田 崇”鶴谷 善昭”野宮 正範" 楖田 信博"

鎌田 竜彦" 本田和也" 中村隆行"相川健"山口 修”

【目的】超音波検查によって前立腺肥大症 (BPH) の術前に前江 腺重量がある程度正確に測定できるようになった。今问、TURP 切除重量/術前経直腸的超音波断層法(TRUS)下推定前泣腺重量 比(縮小率と略) と他覚所見改善度の関連性について検討した。

【方法】TRUS後手術を受けたBPH60例(OPSU群18例、TURP群 42例)を対象とした。TURP群䗆小縮事加0.5以上をI群(28例)、0.5 未満をII群(14例)に分けた。術前、術後 1 ケ月時に最人永流深 (Qmax)、残尿 $(\mathrm{RV})$ 索比較検討した。【結果】術前TRUS重量抒 よび摘出(切除)重量は、OPSU (開腹手術) 群では83.7士30.2gr、 $67.1 \pm 32.0 \mathrm{gr} て ゙ そ の$ 相関伱数R2は0.8628であった。一方TURP群で

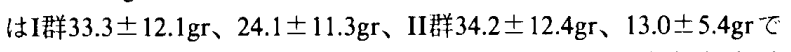
あった。各群において Qmax、RVは術前後で統計上有意差 $(\mathrm{P}<0.01)$ をむって改善したか、判定基準をQmaxは術前より $5 \mathrm{ml}$ / sec以上の上昇、 $\mathrm{RV}$ は $50 \%$ 以上の減少あるいは50ml以下となっ た症例を改善之定義した場合、Qmax、RVの改善象はOPSU群 $16 / 18(88.9 \%) 、 11 / 16(68.8 \%) 、$ TURP I 群 $22 / 28(78.6 \%)$ 、 15/20(75.0\%)、TURP II群5/14(35.7\%)、4/11(36.4\%)であ った。【結語】臨林に則した判定基準を用いた場合TURP I群之 II群の間に他覚所見の改善に差があることよりTURP時はTRUS 推定重量の50\%以上の切除を心がけるべきと思われた。

前立腺肥大症 経尿道的前立腺切除術 尿流残尿測定

\section{MP-375 前立腺肥大症に対する経尿道的前立腺切除 術の長期成績}

\section{北里大学 医学部 泌尿器科"}

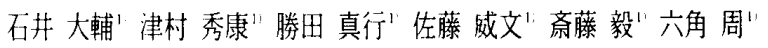

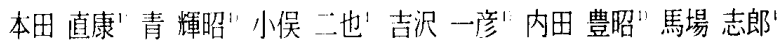

【日的】経尿道的前汒腺切除術は、前立腺肥大症に対する標準的 な治撩法として広く施行されている。今回われわれは1994〜1996 年にTURPを施行し、術後1年以上経過した 64 例の前立腺肥大 症について術㣪1 5年まての舆期臨床効果につき检討した。【対 象および方法】症例は QOL スコア3点以上、I-PSSは8 点以上、 Qmaxは15 $\mathrm{ml} /$ 秒以下の症例で、尿閉症例は除外した。平均年 齢は 67.8 歳(52 84歳)、平均手術時間は 50.5 分(7-195 分), 平均切除是は22.2 g(3.75g)であった。【結果】QOLスコア、 I-PSS, Qmax全て術後 $1 \sim 5$ 年まで有意代改善した $(\mathbf{p}<0.0001)$ 。 臨床効果判定基準による效果判定では術後1年 $82.7 \%$ （64 例）, 2 年 $85.1 \%(27$ 例)，3年 $78.8 \%(19$ 例)，4年 90 . $8 \%$ （11 1 例)，5年 $85.6 \%$ （7例）が有効以上であった。 なお経過镜察中に無効およびやや有効を示した15例の原因とし ては、神経因性膀胱3例、外尿道口部㹟窄 2 例、膀胱䅡部硬化症 1例、㲾道㹟窄1例、不明 8 例ですった。術中・術後合併症は10例 （15.6\%）に認如られた。本法は長期的効果が期待できる方 法であり、今後とも前立腺肥大症に対する gold standardとして残 っていくもの上思わ机る。

\section{前立腺肥大症 経尿道的前立腺切除術 長期成縝}

\section{MP-376 経尿道的前立腺切除術における術前 Pressure Flow Studyと治療効果の検討}

\section{関西医大 11}

佐藤 尚"島田治" 川端和史"壇野祥三”藤田一郎” 大口 尚基" 室田 卓之"川喜田 睦司"松田 公志"

【目的】術前Pressure Flow Study(PFS)で下部成路閉塞を尗たた むのは、経尿道的前立腺切除術 (TUR-P) で排尿状態が改善した か否か評価した。【対象と力法】1997年9月から2000年7月までの 間に、TUR-Pの術前にPFSを施行した前立腺肥大班(BPH)61例を 対象とした。PFSの判定にはAbrams-Griffiths nomogramを䏘い、 治療効果は、I-PSS、QOLindex、Qmaxで評価した。【結果】PFS の結果、Obstructed : 51例、equivocal : 9例、unobstructed : 1例で あった。排尿筋収縮力低下は61例中19例に認めた。術前後のIPSS はObstructed : $18.0 \pm 6.4 か ら 5.9 \pm 4.6$, equivocal : $11.7 \pm 6.8$ から 6.7 土4.6、QOLはObstructed : $4.6 \pm 1.3$ から $1.5 \pm 1.1$ 、 equivocal : 4.3

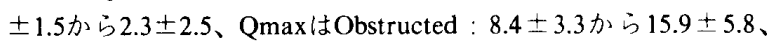
equivocal : $10.3 \pm 3.1$ から $11.3 \pm 7.6 \mathrm{ml} / \mathrm{s}$ 、に改善した。Qmaxは Obstructed とequivocal との間に有意差を諗めた。排尿筋収維力に よる違いは、Week detrusorよりも、Normal detrusorのほうが治 療効果が高い印象を受けたが有意差は珰めなかった。【結論】 Obstructed、Normal detrusorを示した症例は千術による改善度が 高く、術前PFSは有用である。

Pressure flow study 前立腺肥大症 TUR-P 